\title{
Occurrence of the autofluorescent pigment, lipofuscin, in polar crustaceans and its potential as an age marker
}

Accepted: 19 March 2001 / Published online: 30 June 2001

(C) Springer-Verlag 2001

\begin{abstract}
In crustaceans, the lack of reliable methods often prevents the determination of individual age. The quantification of the autofluorescent age pigment, lipofuscin, has revealed promising results in boreal and tropical species. We studied the presence of morphological lipofuscin and its possible application as an age marker in five Arctic and five Antarctic species, comprising decapods, amphipods and a euphausiid. Lipofuscin granules were located in the brain, using confocal fluorescence microscopy, and quantified from digital images. The pigment was found in 94 of 100 individuals and in all 10 species, and granules occurred in easily detectable amounts in 5 species. Two scavenging amphipod species, the Antarctic Waldeckia obesa and the Arctic Eurythenes gryllus, revealed the most conspicuous and numerous granules. There was a broad, though weak, correlation of lipofuscin concentration with individual body size within a species, but not with absolute body size of one species compared to another. In larvae of the decapod Chorismus antarcticus, lipofuscin accumulation was quantified over the 1st 4 months after larval release. Morphological lipofuscin is a potential index of age in those investigated species with a sufficient accumulation rate of the pigment.
\end{abstract}

\section{Introduction}

Individual age is a basic parameter in population dynamics, required for calculating growth, mortality,

This paper presents results of the Midterm Symposium of the SCAR programme "Ecology of the Antarctic Sea Ice Zone" (EASIZ). The manuscript was edited by W. Arntz and A. Clarke.

B.A. Bluhm $(\bowtie) \cdot T$. Brey

M. Klages · W.E. Arntz

Alfred-Wegener-Institut für

Polar- und Meeresforschung,

Columbusstrasse,

27515 Bremerhaven, Germany

E-mail: fsbab@uaf.edu productivity, maturation etc. The few attempts to determine age in polar crustaceans (e.g. Bregazzi 1972; Rakusa-Suszczewski 1982; Gorny et al. 1993; Klages 1993) have predominantly used size-based data, as crustaceans lack permanent hard structures carrying potential age markers. The separation of size-frequency distributions into cohorts is hampered by interference between age classes and moulting stages (Klages 1993) and insufficient resolution in long-lived slow-growing species owing to variation in individual growth (France et al. 1991). Currently, a promising alternative approach is to quantify the autofluorescent age pigment, lipofuscin (Belchier et al. 1994, 1998; Sheehy et al. 1994, 1995, 1996; O’Donovan and Tully 1996).

The existence of morphological lipofuscin (as opposed to soluble or extractable age pigments) has been demonstrated in post-mitotic tissue such as nerve tissue, heart and muscles of various invertebrates and vertebrates (e.g. Donato and Sohal 1978; Bassin et al. 1982; Hunter and Vetter 1988; Clarke et al. 1990; Girven et al. 1993). Free radical-induced lipid peroxidation processes are thought to lead to the formation of lipofuscin (Sohal 1981; Zs-Nagy 1988). Accumulation of the pigment over the lifespan of an individual appears to be a universal correlate of animal senescence. For crustaceans, a solvent extraction method (Ettershank 1983, 1984) was used to quantify lipofuscin in several species (Hirche and Anger 1987; Sheehy and Ettershank 1988) including the Antarctic krill, Euphausia superba (Ettershank 1983, 1984; Berman et al. 1989, Nicol et al. 1991). Sheehy (1996), however, demonstrated that soluble autofluorescence bears no quantitative relationship to lipofuscin. The author concluded that the histologically based quantitative method with concurrent visual microscopic verification of in situ morphological lipofuscin's fluorescence and histochemical attributes is the only reliable method for quantification. Several recent studies have been attempted to assess the applicability of morphological lipofuscin as an age marker (O'Donovan and Tully 1996; Belchier et al. 1998; Sheehy et al. 1998). Besides 
E. superba (Sheehy 1990a), no other species from high latitudes has been studied until now.

The two major aims of this study are: (1) to investigate the occurrence of lipofuscin in selected polar crustacean species, and (2) to assess the potential of image analysis of morphological lipofuscin as a quantification procedure for the age-marker pigment. Five species each from the Arctic (two amphipod and three decapod species) and the Antarctic (one amphipod, one euphausiid and three decapod species), covering different taxa, feeding types and bathymetric distribution ranges, were examined for the occurrence of lipofuscin and its age-dependent accumulation.

\section{Materials and methods}

Sampling

Specimens from the Antarctic (Table 1) were caught between $170 \mathrm{~m}$ and $2,100 \mathrm{~m}$ depth during the expedition ANT XV/3 (EASIZ II, 1998) of R/V Polarstern to the eastern Weddell Sea. Average annual temperature close to the sea bottom ranges from $0.4^{\circ} \mathrm{C}$ (Circumpolar Deep Water) to $-1.8^{\circ} \mathrm{C}$ (Antarctic Surface Water), with seasonal variability generally $<0.8^{\circ} \mathrm{C}$ (Hellmer and Bersch 1985; Arntz et al. 1992). Specimens from the Arctic (Table 1) were caught during the expeditions ARK XIII/1 + 2 (1997) to the northern Barents and Greenland Seas, and ARK XV/1 (1999) to the Greenland Sea at depths between 140 and $5,550 \mathrm{~m}$. Average annual temperatures close to the sea bottom in these areas are $+0.5^{\circ} \mathrm{C}$ to $-1.5^{\circ} \mathrm{C}$ (Coachman and Aagard 1979; Loeng 1989) with minimal seasonal variation. All investigated specimens were fixed in $4 \%$ buffered formaldehydeseawater solution immediately after sorting the catches, and were stored in the solution until analysis in summer 1999.

Life maintenance

Several females of Chorismus antarcticus were caught with fertilised eggs attached to the pleopods in January to March 1998. In September/October 1998, 11 females released zoea I-stage larvae, which were transferred to $100-\mathrm{ml}$ plastic bottles. The larvae were fed with live Artemia spp. nauplii and water was replaced every other day. They were reared at $0 \pm 0.2^{\circ} \mathrm{C}$. At intervals, some larvae were fixed in $4 \%$ buffered formaldehyde-seawater solution for lipofuscin analysis. After 4 months all larvae were fixed, or had died.

Sample preparation

Sex, wet weight and body size were recorded (carapace length in decapods to the nearest $0.1 \mathrm{~mm}$, and body length from rostrum to the end of the telson to the nearest millimetre in
Table 1 Species investigated in the present study. Depth ranges and feeding types are added from the literature if available

\begin{tabular}{|c|c|c|c|c|c|}
\hline \multirow[t]{2}{*}{ Species } & \multirow[t]{2}{*}{ Taxonomy } & \multirow[t]{2}{*}{ Sampling area } & \multicolumn{2}{|c|}{ Depth range $(\mathrm{m})$} & \multirow[t]{2}{*}{ Feeding type } \\
\hline & & & Min. & Max. & \\
\hline \multicolumn{6}{|l|}{ Arctic } \\
\hline $\begin{array}{l}\text { Eurythenes gryllus } \\
\quad \text { (Lichtenstein, 1822) }\end{array}$ & $\begin{array}{l}\text { Lysianassidae s.l., } \\
\text { Amphipoda }\end{array}$ & Greenland Sea & $0^{\mathrm{c}}$ & $6500^{\mathrm{c}}$ & Scavenger ${ }^{\mathrm{h}}$ \\
\hline $\begin{array}{l}\text { Uristes sp. Dana, } \\
1849\end{array}$ & $\begin{array}{l}\text { Lysianassidae s.l., } \\
\text { Amphipoda }\end{array}$ & Greenland Sea & $?$ & $5550^{\mathrm{a}}$ & Scavenger $^{\mathrm{a}}$ \\
\hline $\begin{array}{l}\text { Sabinea } \\
\quad \text { septemcarinata } \\
\text { Sabine, } 1821\end{array}$ & $\begin{array}{l}\text { Crangonidae, } \\
\text { Decapoda }\end{array}$ & Barents Sea & $30^{\mathrm{g}}$ & $300^{\mathrm{g}}$ & Predator $^{\mathrm{a}}$ \\
\hline $\begin{array}{l}\text { Sclerocrangon ferox } \\
\text { Sars, } 1877\end{array}$ & $\begin{array}{l}\text { Crangonidae, } \\
\text { Decapoda }\end{array}$ & Barents Sea & $100^{\mathrm{g}}$ & $1000^{\mathrm{g}}$ & Predator $^{\mathrm{a}}$ \\
\hline $\begin{array}{l}\text { Pandalus borealis } \\
\text { Krøyer, } 1844\end{array}$ & $\begin{array}{l}\text { Pandalidae, } \\
\text { Decapoda }\end{array}$ & Greenland Sea & $150^{\mathrm{g}}$ & $700^{\mathrm{g}}$ & $\begin{array}{l}\text { Predator, } \\
\quad \text { omnivorous }^{1}\end{array}$ \\
\hline \multicolumn{6}{|l|}{ Antarctic } \\
\hline $\begin{array}{l}\text { Waldeckia obesa } \\
\text { (Chevreux, 1905) }\end{array}$ & $\begin{array}{l}\text { Lysianassidae s.l., } \\
\text { Amphipoda }\end{array}$ & Weddell Sea & $0^{\mathrm{d}}$ & $900^{\mathrm{a}}$ & Scavenger $^{\mathrm{a}}$ \\
\hline $\begin{array}{l}\text { Euphausia superba } \\
\text { Dana, } 1850\end{array}$ & $\begin{array}{l}\text { Euphausiidae, } \\
\text { Euphausiacea }\end{array}$ & Weddell Sea & & Pelagic & $\begin{array}{l}\text { Herbivorous } \\
\text { filterfeeder/ } \\
\text { icescraper }^{\mathrm{j}}\end{array}$ \\
\hline $\begin{array}{l}\text { Nematocarcinus } \\
\quad \text { lanceopes Bate, } 1888\end{array}$ & $\begin{array}{l}\text { Nematocarcinidae, } \\
\text { Decapoda }\end{array}$ & Weddell Sea & $600^{\mathrm{b}}$ & $2505^{\mathrm{e}}$ & $\begin{array}{l}\text { Predator, } \\
\text { omnivorous }^{\mathrm{k}}\end{array}$ \\
\hline $\begin{array}{l}\text { Notocrangon antarcticus } \\
\quad \text { (Pfeffer, 1887) }\end{array}$ & $\begin{array}{l}\text { Crangonidae, } \\
\text { Decapoda }\end{array}$ & Weddell Sea & $5^{\mathrm{i}}$ & $1320^{\mathrm{e}}$ & $\begin{array}{l}\text { Predator, } \\
\text { omnivorous }^{\mathrm{f}}\end{array}$ \\
\hline $\begin{array}{l}\text { Chorismus antarcticus } \\
\quad \text { (Pfeffer, 1887) }\end{array}$ & $\begin{array}{l}\text { Hippolytidae, } \\
\text { Decapoda }\end{array}$ & Weddell Sea & $5^{\mathrm{i}}$ & $915^{\mathrm{e}}$ & $\begin{array}{l}\text { Predator, } \\
\text { omnivorous }^{\mathrm{f}}\end{array}$ \\
\hline
\end{tabular}

${ }^{\text {a }}$ Personal observations

bArntz and Gorny (1991)

${ }^{\mathrm{c}}$ Barnard and Karaman (1991)

${ }^{\mathrm{d}}$ DeBroyer and Klages (1990)

${ }^{\mathrm{e}}$ Gorny (1999)

${ }^{\mathrm{f}}$ Gorny et al. (1992)

${ }^{\mathrm{g}}$ Heegard (1941)

${ }^{\mathrm{h}}$ Ingram and Hessler (1983)

${ }^{\mathrm{i}}$ Kirkwood and Burton (1988)

${ }^{\mathrm{j}}$ Reid et al. (1999)

${ }^{\mathrm{k}}$ Wenner (1979)

${ }^{1}$ Wienberg (1981) 
amphipods and euphausiids). Brains of the investigated species were prepared for lipofuscin measurement essentially as described for various decapod species by Sheehy (1989, 1990a) and Sheehy and Wickins (1994). The brains were dissected and dehydrated in ascending ethanol concentrations from $70 \%$ to $100 \%$. For the larvae of $C$. antarcticus, complete heads were embedded due to the small size. Unstained, serial, $6-\mu \mathrm{m}$ resin (Technovit, Kultzer) sections were prepared following standard embedding procedures excluding, however, mounting medium. Figure 1 shows how brains were orientated and serially sectioned.

Fluorescence microscopy

Sections were analysed with an inverted Leica TCS NT confocal microscope, using $488 \mathrm{~nm}$ excitation wavelength of a KrAr laser (Omnichrome) and a $\times 40$ oil immersion lens with a high numerical aperture of 1.25 . The sections were additionally viewed using an HBO 50 mercury lamp and $365 \mathrm{~nm}$, as well as 450-nm excitation filters fitted to the same microscope to assess the colour of the fluorescence. In decapods, the (posterior) lateral somacluster of the olfactory lobe was localised (nomenclature after Sandeman et al. 1992); this is composed of cell bodies of ascending olfactory projection neurons (Schmidt and Harzsch 1999). Lipofuscin has proven to be especially dense in this area in decapod crustaceans (Sheehy 1989, 1990b; Sheehy et al. 1995, 1998). In amphipods, we identified regions of high lipofuscin density, so far not described in the literature, and afterwards used them for analysis. In E. superba, the entire brains were scanned for lipofuscin. Six, approximately equidistant, sections of the investigated brain areas were selected for lipofuscin analysis. Digital images of $1,024 \times 1,024$ pixels resolution $(250 \times 250 \mu \mathrm{m}$ frame area) were recorded, applying Kalman averaging of 4 images each to reduce noise. Photomultiplier intensity, laser power and offset were adjusted whenever necessary.

Lipofuscin quantification

Image analysis was carried out using "Image" software (National Institute of Health). Autofluorescent lipofuscin granules were discriminated using manual greyscale thresholding. The total area

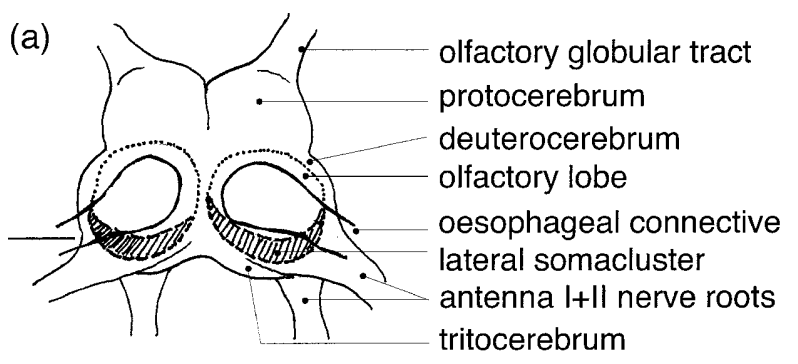

(b)

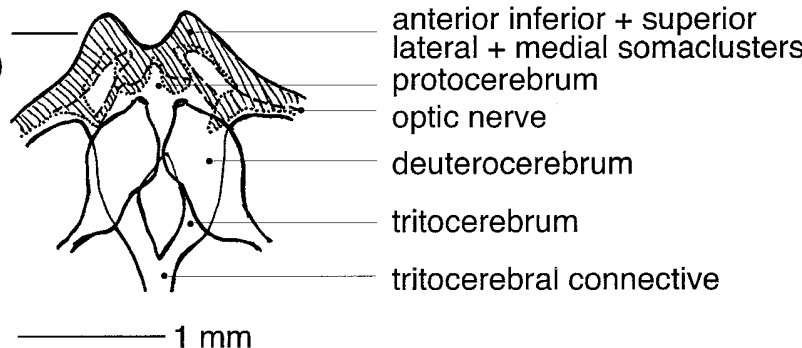

Fig. 1 Schematic views of the brains of a medium-sized a caridean decapod, and b lysianassoid amphipod. Hatchings mark the tissue areas used for lipofuscin quantification. Horizontal lines indicate the planes of sectioning fraction of lipofuscin granules in the binarised selected area of the images was calculated by dividing the area of lipofuscin granules by the total area of analysed tissue, multiplied by 100 . Finally, the geometric average area fraction over all analysed sections per specimen was computed (which - in line with stereological convention - corresponds to volume fraction in \% lipofuscin).

\section{Histochemistry}

The characteristic lipophilia of lipofuscin was confirmed in selected sections of each species by staining with Sudan Black. The resin sections were rehydrated in graded ethanols $(95 \%, 90 \%, 80 \%$, $70 \%$ ) for 2 min each. They were then stained by immersion in a saturated solution of filtered Sudan B in $70 \%$ ethanol for at least $30 \mathrm{~min}$ (modified after Romeis 1968 and Sheehy and Wickins 1994). After rinsing excess stain with ethanol and water, the sections were dried on a heating table for $5 \mathrm{~min}$. The same sections that had been recorded for lipofuscin autofluorescence were recorded digitally for Sudan B staining. Again, no cover glass was applied.

\section{Results}

Morphological lipofuscin was found in 94 of 100 individuals and in all species (Table 2). Granules were detected in considerable amounts in five of the ten investigated species, and lipofuscin concentrations ranged from $<0.01$ to $1 \%$ lipofuscin area fraction (excluding Waldeckia obesa which cannot be directly compared, see below). The two scavenging amphipod species, Eurythenes gryllus and $W$. obesa, revealed the most conspicuous and largest granules with the most intense fluorescence. Among the decapod species, comparatively high concentrations were found in Notocrangon antarcticus, C. antarcticus and Sclerocrangon ferox (max. $0.2 \%$ area fraction). Only single small granules were discriminated in the amphipod Uristes sp., in the decapods Pandalus borealis, Sabinea septemcarinata and Nematocarcinus lanceopes and in the euphausiid Euphausia superba.

In the investigated decapod species, the autofluorescent, roundish to irregularly shaped granules of predominantly $1-5 \mu \mathrm{m}$ in size were observed in the posterior lateral somacluster of the olfactory lobe (Fig. 1), as known from other decapod species. In amphipods, lipofuscin granules of comparable shape and average size but of higher maximum size, probably due to aggregation, were associated with the anterior inferior lateral and medial somaclusters (and associated bridge), and the anterior superior lateral and medial somaclusters (nomenclature after MacPherson and Steele 1980; Fig. 1). In Eurythenes gryllus, lipofuscin granules concentrated in dense aggregations in which single granules seemed to merge. These aggregations were more or less evenly distributed over the somaclusters. Granules were also found in neuropils and nervecords, though in less dense aggregates. In $W$. obesa, however, lipofuscin concentrated in the transition zone between the somaclusters and the associated neuropils, and was not found in the clusters themselves. For analysis, a different portion of the tissue was therefore selected in this spe- 
Table 2 Lipofuscin concentrations in individuals of ten polar crustacean species: summary of the survey results. Lipofuscin concentration means and standard deviations of the image analysis of six brain sections per specimen are given. Maximum sizes and estimates for maximum ages of the species are added from the literature if available [ $B L$ body length (Amphipoda, Euphausiacea), $C L$ carapace length (Decapoda), $f e$ female, $m a$ male, $N$ sample size; bold type conspicuous concentrations of lipofuscin]. Note that most estimates of maximum age of species are based on size-data and should for reasons discussed in the text be interpreted with caution

\begin{tabular}{|c|c|c|c|c|c|c|c|}
\hline \multirow[t]{2}{*}{ Species } & \multirow[t]{2}{*}{$\begin{array}{l}\text { Depth of } \\
\text { sampling } \\
(\mathrm{m})\end{array}$} & \multirow[t]{2}{*}{$N$} & \multirow[t]{2}{*}{$\begin{array}{l}\text { Size range } \\
\text { analysed } \\
(\mathrm{mm} \mathrm{CL} / \mathrm{BL})\end{array}$} & \multirow{2}{*}{$\begin{array}{l}\text { Max. size } \\
\text { in study } \\
\text { area } \\
(\mathrm{mm} \mathrm{CL} / \mathrm{BL})\end{array}$} & \multirow[t]{2}{*}{$\begin{array}{l}\text { Wet weight } \\
\text { range } \\
\text { analysed }(\mathrm{g})\end{array}$} & $\begin{array}{l}\text { Lipofuscin } \\
\text { concentration range } \\
(\% \text { area fraction }) \pm \mathrm{SD}\end{array}$ & \multirow{2}{*}{$\begin{array}{l}\text { Estimated } \\
\text { max. age } \\
\text { of species } \\
\text { (years) }\end{array}$} \\
\hline & & & & & & Max. & \\
\hline
\end{tabular}

\section{Arctic}

Eurythenes

gryllus

Uristes sp.

Sabinea

septemcarinata

Sclerocrangon

ferox

Pandalus

borealis

Antarctic

Waldeckia

Euphausia

superba

lanceopes

Notocrangon

antarcticus

Chorismus

antarcticus
Nematocarcinus

$\begin{array}{rcccl}2500 & 3 & 33 & 50 & 140^{\mathrm{g}} \\ 5550 & 2 & 5 & 8 & 14^{\mathrm{a}} \\ 160 & 6 & 8.8 & 16.4 & \text { BL80 } \\ & & & & \text { CL } 18.0^{\mathrm{a}} \\ 160-300 & 4 & 12.8 & 21.7 & 29.9^{\mathrm{a}} \\ 300 & 6 & 8.1 & 22.4 & 25^{\mathrm{j}}\end{array}$

\section{$0.9 \quad 3.2$}

$0.17 \pm 0.04$

$\mathbf{1 . 0 4} \pm 0.21 \quad 9(\mathrm{fe}) / 4(\mathrm{ma})^{\mathrm{h}}$

$0.005 \quad 0.013<0.01$

0.8

4.0

0

$3.3 \quad 11.4<0.01$

$0.5 \quad 8.2$

0

$0.01 \pm<0.01 \quad ?$
$0.02 \pm<0.01 \quad 4-6^{k}$

$\mathbf{0 . 0 7} \pm 0.03 \quad 4-6^{\mathrm{k}}$

$0.01 \pm<0.01 \quad 6^{i}$

\begin{tabular}{|c|c|c|}
\hline 0.45 & $0.44 \pm 0.07$ & $2.79 \pm$ \\
\hline 1.0 & 0 & $<0.01$ \\
\hline 11.1 & $<0.01$ & $0.01 \pm$ \\
\hline 12.9 & $<0.01$ & $0.21 \pm$ \\
\hline 5.8 & $<0.01$ & $0.21 \pm$ \\
\hline $\begin{array}{l}\text { ad Hessler } \\
\text { ad Hessle } \\
(1988) \\
(1983) \\
\text { i (1987) }\end{array}$ & $\begin{array}{l}\text { 83) } \\
\text { 87) (age at }\end{array}$ & turity) \\
\hline
\end{tabular}

${ }^{\mathrm{g}}$ Ingram and Hessler (1983)

${ }^{\mathrm{h}}$ Ingram and Hessler (1987) (age at maturity)

${ }^{\mathrm{i}}$ Marschall (1988)

${ }^{\mathrm{j}}$ Teigmark (1983)

${ }^{\mathrm{k}}$ Weslawski (1987)

${ }^{\mathrm{e}} \mathrm{G}$. Chapelle, personal communication

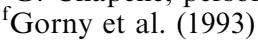

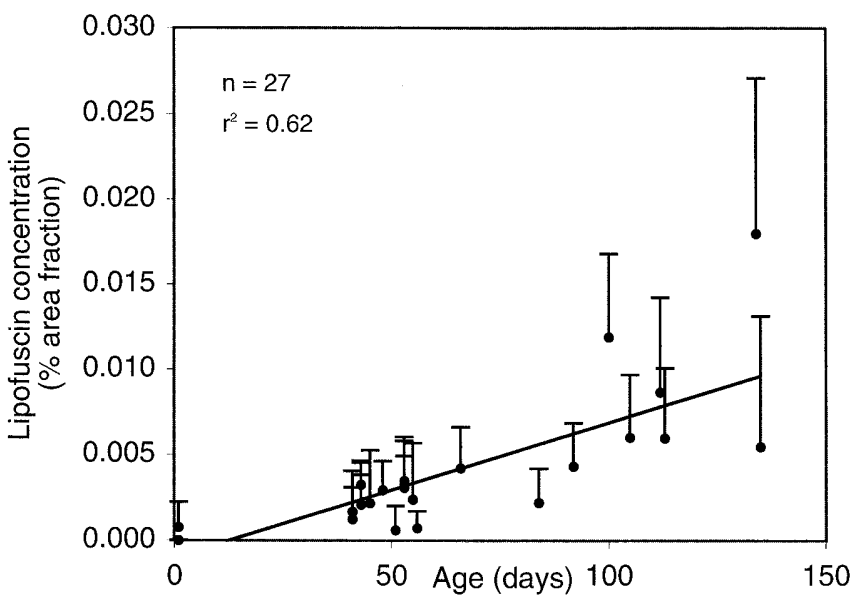

Fig. 2 Relationship between age and lipofuscin in the lateral somacluster of the olfactory lobe of Chorismus antarcticus larvae. Means and standard deviations of the image analysis of six brain sections per specimen are given

cies. This increased absolute values of concentrations and, thereby, made them incomparable to other species, but reduced the standard deviation between sections of one individual. In the euphausiid, lipofuscin neither occurred in somaclusters nor in nerve cords and neuropils in considerable amounts.

In laboratory-reared larvae of $C$. antarcticus, agedependent accumulation of lipofuscin was quantified over the 1st 4 months after larval release (Fig. 2). Granules were, however, inconspicuous and comparatively small $(1-2 \mu \mathrm{m}$ in diameter, max. $4 \mu \mathrm{m})$. No lipofuscin was found in freshly released larvae, whereas a concentration of up to $0.02 \%$ area fraction ( $\mathrm{SD}=0.008 \%$ area fraction), an order of magnitude lower than maximum concentrations found in adults, was measured in 4-month-old individuals. Within the analysed age range, a linear regression fits the data best.

Among the species with considerable amounts of lipofuscin, small and supposedly young individuals within a species tended to contain less lipofuscin than much larger, heavier and supposedly older ones, as shown for $W$. obesa, Notocrangon antarcticus and the protandrous hermaphrodite, C. antarcticus, in Fig. 3. Within similar sizes, however, different lipofuscin concentrations were observed. Among the species with negligible amounts of lipofuscin, no such trend was measured. In amphipods, the two larger species contained considerably more pigment than the small spe- 
Fig. 3 Relationship between body size and body weight, respectively, and lipofuscin concentration in $\mathbf{a}, \mathbf{b}$ the amphipod Waldeckia obesa $(n=32), \mathbf{c}, \mathbf{d}$ the decapod Notocrangon antarcticus $(n=20)$, and $\mathbf{e}, \mathbf{f}$ the decapod Chorismus antarcticus $(n=14)$ (dots females, circles males, squares larvae). Means and standard deviations of the image analysis of six brain sections per specimen are given. Larvae of C. antarcticus were not weighed to avoid damage
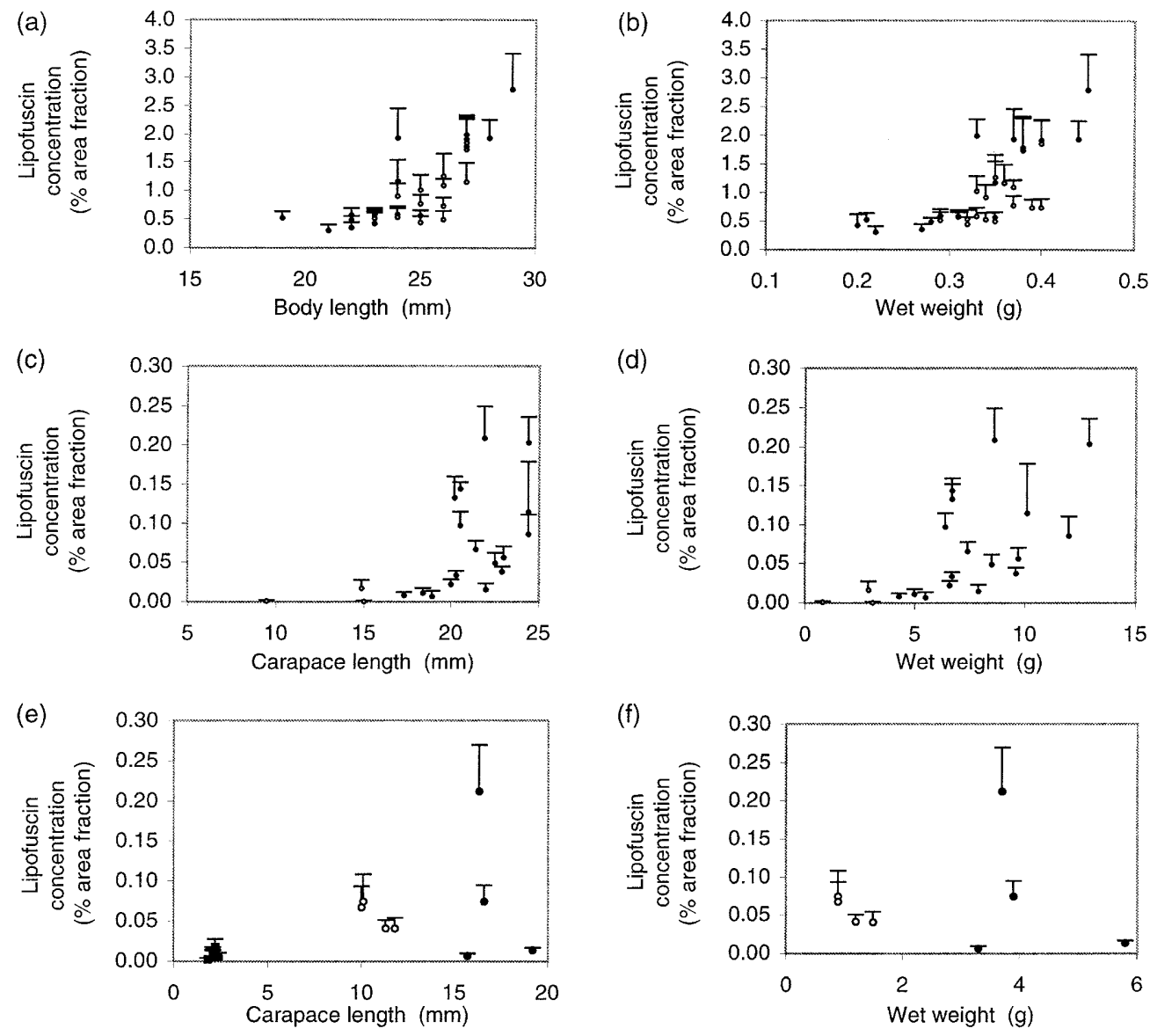

cies, although it must be noted that the maximum size of Uristes sp. is not definitely known as yet. Nematocarcinus lanceopes, however, with the largest absolute body size of the investigated decapod species, contained considerably lower lipofuscin concentrations than the smaller species Notocrangon antarcticus and C. antarcticus. Highest maximum concentrations within a species were found in female specimens compared to males (Fig. 3).

\section{Discussion}

This study confirms the occurrence of morphological lipofuscin in polar crustaceans for the first time. All investigated Arctic and Antarctic species displayed at least some lipofuscin granules. The granules were conspicuous in five of the ten investigated species, with considerable variability in density and fluorescence intensity between species. Unlike the lipofuscin distribution in all decapods investigated so far, lipofuscin in the amphipod $W$. obesa did not occur within the somaclusters but between somaclusters and neuropils. Up to this point we have no explanation for this phenomenon. Those specimens without obvious pigment granules do not necessarily lack the pigment, but granules may not have been detectable with the applied methodology. Although we tried to include specimens close to the known maximum size of the species, age-pigment concentrations ranged an order of magnitude lower than measured in species from lower latitudes (Sheehy et al. 1994, 1998; Belchier et al. 1998).

Lipofuscin has been called a physiological age marker, associated with "subjective" (life)time passing at an individual's or species' pace, as opposed to objective time passing at the same pace universally. "Subjective" time is a function of the metabolic "clock", which in turn depends on genetic as well as environmental parameters. Formation and accumulation of lipofuscin may, therefore, be affected by spatial and temporal environmental variability (Sheehy et al. 1996). Temperature has been identified as one of the primary factors, as metabolic rate increases with temperature. O'Donovan and Tully (1996), for example, found a significant difference in lipofuscin accumulation of European lobsters kept at $8^{\circ} \mathrm{C}$ and $13^{\circ} \mathrm{C}$. Hence, the rate of formation and accumulation of lipofuscin in polar crustaceans can be expected to be low compared to lower latitudes.

Food availability and, therefore, caloric intake are the second important parameter affecting metabolism and lipofuscin formation processes. After starvation of individuals of $W$. obesa for 64 days, Chapelle et al. (1994) measured a decrease of oxygen consumption to 
$60 \%$ which, after feeding, went straight up again. These findings indicate that short-term lipofuscin accumulation rates may vary considerably. On longer time scales, however, short-term metabolic variability will not affect overall lipofuscin accumulation rates.

Generally, food availability over the year is lower in the study areas of this investigation than in shelf areas of lower latitudes (summarised in Arntz et al. 1992). This, in combination with low temperatures and, consequently, comparatively low standard metabolism (Chapelle and Peck 1995), is assumed to lead to the slow growth and high longevity observed in many polar invertebrates. Slow ageing processes cause low lipofuscin accumulation rates (Nakano et al. 1995), and hence the comparatively low observed amounts of lipofuscin found in this study are not surprising.

Beside environmental variability, genetically determined factors inherent to a species and/or individual, such as the activity level or feeding type, can affect lipofuscin accumulation. Our data, however, are inconclusive in this respect. Eurythenes gryllus, for example, known for its strong swimming ability (Ingram and Hessler 1987; Hargrave et al. 1995), displays high lipofuscin concentrations whereas Euphausia superba, also permanently active, lacks conspicuous granules. Looking at feeding types, the scavenging amphipods contain more lipofuscin than the predatory decapods, as well as the predominantly herbivorous euphausiid. Obviously, an insufficient number of species has been investigated so far to discern a clear pattern. Moreover, we know little about differences between taxa when regarding metabolic processes leading to lipofuscin generation. Hence, the crucial factor causing the pronounced differences between species remains unknown.

There are two possibilities for calibrating lipofuscin concentration against age: (1) analysis of a group of individuals of known age, covering as much of a species' lifespan as possible; (2) statistical separation of a lipofuscin-frequency distribution, analogous to the commonly used size-frequency distributions, into distinct groups representing age classes (Sheehy et al. 1998).

For obvious logistic reasons, calibration by an agelipofuscin relation is rarely possible in polar species. We measured age-dependent lipofuscin accumulation directly in laboratory-reared $C$. antarcticus larvae over the 1st 4 months after larval release $(11$ months after the eggs have become attached to the pleopods; Gorny et al. 1993). Lipofuscin concentrations were very low and granules were inconspicuous, as also observed by Sheehy (1990a) and Sheehy et al. (1994) in Cherax quadrinatus during the initial months. As in this study, Sheehy (1990b), O'Donovan and Tully (1996) and Sheehy et al. (1998) observed linear accumulation in juveniles but cautioned against extrapolation of this pattern to total life span. Sheehy (1992) and Sheehy et al. (1994), however, observed apparently decelerating accumulation with advancing age.

Slow growth in mature individuals combined with individual variability in growth lead to a merging and pile-up of age classes towards the larger size classes in size-frequency distributions (e.g. Arntz and Gorny 1991; Sheehy et al. 1998), which hamper statistical separation of age classes. Present data indicate that, in those species, the relation between age and lipofuscin is much less variable than the relation between age and body size, thus making lipofuscin-frequency distributions more suitable for age-class separation (Sheehy et al. 1994, 1998).

Our findings are encouraging for the future use of lipofuscin for age determination in those of the investigated species displaying a sufficiently high increase in lipofuscin concentration over their life spans. None of the factors potentially influencing lipofuscin formation are presently considered sufficient to reject the applicability of the method. Stable environmental temperatures and long life spans integrating short-term variations could possibly be helpful in lipofuscin analysis. A study is currently underway to assess population-age distribution in the amphipod $W$. obesa and the decapod Notocrangon antarcticus, by applying a lipofuscin age index.

Acknowledgements This project was financed by the German Research Foundation DFG ( $\mathrm{Br} 1220 / 4-1)$. The help and support of the "Polarstern" crew and colleagues on board and in the A.W.I. is acknowledged. Special thanks are due to Kerstin Beyer, Katrin Premke and Evelin Siebert for technical assistance. We are grateful to M.R.J. Sheehy and an anonymous referee for the improvement of an earlier draft of the manuscript. This is A.W.I. publication no. 1779 .

\section{References}

Arntz WE, Gorny M (1991) Shrimp (Decapoda, Natantia) occurrence and distribution in the eastern Weddell Sea, Antarctica. Polar Biol 11:169-177

Arntz WE, Brey T, Gerdes D, Gorny M, Gutt J, Hain S, Klages M (1992) Patterns of life history and population dynamics of benthic invertebrates under high Antarctic conditions of the Weddell Sea. In: Colombo G, Ferrari I, Ceccherelli VU, Rossi $\mathrm{R}$ (eds) Marine eutrophication and population dynamics. Proceedings of the 25th European Marine Biology Symposium. Olsen \& Olsen, pp 221-230

Barnard JL, Karaman GS (1991) The families and genera of marine gammaridean Amphipoda (except marine Gammaroidea). Rec Aust Mus 13 [Suppl]:886

Bassin ABK, Terblanche SE, Oelofsen W (1982) A comparative study on the effects of ageing and training on the levels of lipofuscin in various tissues of the rat. Comp Biochem Physiol 71A:369-374

Belchier M, Shelton PMJ, Chapman CJ (1994) The identification and measurement of fluorescent age pigment abundance in the brain of a crustacean (Nephrops norvegicus) by confocal microscopy. Comp Biochem Physiol 108B:157-164

Belchier M, Edsman L, Sheehy MRJ, Shelton PMJ (1998) Estimating age and growth in long-lived temperate freshwater crayfish using lipofuscin. Freshwater Biol 39:439-446

Berman MS, McVey AL, Ettershank G (1989) Age determination of Antarctic krill using fluorescence and image analysis of size. Polar Biol 9:267-271

Bregazzi PK (1972) Life cycles and seasonal movements of Cheirimedon femoratus (Pfeffer) and Tryphosella kergueleni (Miers) (Crustacea: Amphipoda). Br Antarct Surv Bull 30:1-34 
Chapelle G (1995) Estimating size of amphipods in life cycle studies: what to measure and what for? Pol Arch Hydrobiol 42:295-302

Chapelle G, Peck LS (1995) The influence of acclimation and substratum on the metabolism of the Antarctic amphipods Waldeckia obesa (Chevreux 1905) and Bovallia gigantea (Pfeffer 1888). Polar Biol 15:225-232

Chapelle G, Peck LS, Clarke A (1994) Effects of feeding and starvation on the metabolic rate of the necrophagous Antarctic amphipod Waldeckia obesa (Chevreux, 1905). J Exp Mar Biol Ecol 183:63-76

Clarke A, Kendall MA, Gore DJ (1990) The accumulation of fluorescent age pigments in the trochid gastropod Monodonta lineata. J Exp Mar Biol Ecol 144:185-204

Coachman LK, Aagard K (1979) Physical oceanography of Arctic and Subarctic seas. In: Hermann Y (ed) Marine geology and oceanography of the Arctic seas. pp 1-72

DeBroyer C, Klages M (1990) Studies on amphipod biology. Polarforschung 68:113-115

Donato H, Sohal RS (1978) Age related changes in lipofuscinassociated fluorescent substances in the adult male housefly, Musca domestica. Exp Gerontol 13:171-179

Ettershank G (1983) Age structure and cyclical annual size change in the Antarctic krill, Euphausia superba Dana. Polar Biol 2:189-193

Ettershank G (1984) A new approach to the assessment of longevity in the Antarctic krill Euphausia superba. J Crust Biol 4:295-305

France R, Holmes J, Lynch A (1991) Use of size-frequency data to estimate the age composition of crayfish populations. Can J Fish Aquat Sci 48:2324-2332

Girven RJ, Gauldie RW, Czochanska Z, Woolhouse AD (1993) A test of the lipofuscin technique of age estimation in fish. J Appl Ichthyol 9:82-88

Gorny M (1999) On the biogeography and ecology of the Southern Ocean decapod fauna. In: Arntz WE, Ríos C (eds) MagellanAntarctic: ecosystems that drifted apart. Sci Mar 63 [Suppl 1]:367-382

Gorny M, Arntz WE, Clarke A, Gore DJ (1992) Reproductive biology of caridean decapods from the Weddell Sea. Polar Biol 12:111-120

Gorny M, Brey T, Arntz WE, Bruns T (1993) Growth, development and productivity of Chorismus antarcticus (Pfeffer) (Crustacea: Decapoda: Natantia) in the eastern Weddell Sea, Antarctica. J Exp Mar Biol Ecol 174:261-275

Hargrave BT, Phillips GA, Prouse NJ, Cranford PJ (1995) Rapid digestion and assimilation of bait by the deep-sea amphipod Eurythenes gryllus. Deep Sea Res I42:1905-1921

Heegard PE (1941) The zoology of East Greenland. Decapod crustaceans. Meddr Grønland 121:1-72

Hellmer H, Bersch M (1985) The Southern Ocean. A survey of oceanographic and marine metereological research work. Ber Polarforsch 26:115

Hirche H-J, Anger K (1987) The accumulation of age pigments during larval development of the spider crab, Hyas araneus (Decapoda, Majidae). Comp Biochem Physiol 88B:777-782

Hunter JR, Vetter RD (1988) Accumulation of age pigments (lipofuscin) in two cold-water fishes. Fish Bull 86:401-407

Ingram CL, Hessler RR (1983) Distribution and behavior of scavenging amphipods from the central North Pacific. Deep Sea Res 30:683-706

Ingram CL, Hessler RR (1987) Population biology of the deep-sea amphipod Eurythenes gryllus: inferences from instar analyses. Deep Sea Res 34:1889-1910

Kirkwood JM, Burton HR (1988) Macrobenthos species assemblages in Ellis Fjord, Vestfold Hills, Antarctica. Mar Biol 97:445-457

Klages M (1993) Distribution, reproduction and population dynamics of the Antarctic gammaridean amphipod Eusirus perdentatus Chevreux, 1912 (Crustacea). Antarct Sci $5 \cdot 349-359$

Loeng H (1989) Ecological features of the Barents Sea. In: Rey L, Alexander V (eds) Proceedings of the sixth conference of the
Comité Arctique International 13-15 May 1985. Brill, Leiden, pp 327-365

MacPherson BR, Steele VJ (1980) Microanatomy of the central nervous system of Gammarus setosus Dementieva (Amphipoda). The supraoesophageal ganglion (brain). Crustaceana 38:113-120

Marschall H-P (1988) The overwintering strategy of Antarctic krill under the pack-ice of the Weddell Sea. Polar Biol 9:129-135

Nakano M, Oenzil F, Mizuno T, Gotoh S (1995) Age-related changes in the lipofuscin accumulation of brain and heart. Geronology 41:69-79

Nicol S, Stolp M, Hosie GW (1991) Accumulation of fluorescent age pigments in a laboratory population of Antarctic krill Euphausia superba Dana. J Exp Mar Biol Ecol 146:153-161

O’Donovan V, Tully O (1996) Lipofuscin (age pigment) as an index of crustacean age: correlation with age, temperature and body size in cultured juvenile Homarus gammarus L. J Exp Mar Biol Ecol 207:1-14

Rakusa-Suszczewski S (1982) The biology and metabolism of Orchomene plebs (Hurley, 1965) (Amphipoda: Gammaridea) from McMurdo Sound, Ross Sea, Antarctic. Mar Biol 1:47-54

Reid K, Watkins JL, Croxall JP, Murphy EJ (1999) Krill population dynamics at South Georgia 1991-1997, based on data from predators and nets. Mar Ecol Prog Ser 177:103-114

Romeis B (1968) Mikroskopische Techniken. Oldenbourg, München

Sandeman D, Sandeman R, Derby C, Schmidt M (1992) Morphology of the brain of crayfish, crabs, and spiny lobsters: a common nomenclature for homologous structures. Biol Bull 183:304-326

Schmidt M, Harzsch S (1999) Comparative analysis of neurogenesis in the central olfactory pathway of adult decapod crustaceans by in vivo BrdU labeling. Biol Bull 196:127-136

Sheehy MRJ (1989) Crustacean brain lipofuscin: an examination of the morphological pigment in the fresh-water crayfish Cherax cuspidatus (Parastacidae). J Crust Biol 9:387-391

Sheehy MRJ (1990a) Widespread occurrence of fluorescent morphological lipofuscin in the crustacean brain. J Crust Biol 10:613-622

Sheehy MRJ (1990b) Individual variation in, and the effect of rearing temperature and body size on the concentration of fluorescent morphological lipofuscin on the brains of freshwater crayfish, Cherax cuspidatus (Crustacea: Parastacidae). Comp Biochem Physiol 96A:281-286

Sheehy MRJ (1992) Lipofuscin age pigment accumulation in the brains of ageing field- and laboratory-reared crayfish Cherax quadricarinatus (von Martens) (Decapoda: Parastacidae). J Exp Mar Biol Ecol 161:79-89

Sheehy MRJ (1996) Quantitative comparison of in situ lipofuscin concentration with soluble autofluorescence intensity in the crustacean brain. Exp Geront 31:421-432

Sheehy MRJ, Ettershank G (1988) Extractable age pigment-like autofluorescence and its relationship to growth and age in the water-flea Daphnia carinata King (Crustacea: Cladocera). Aust J Zool 36:611-625

Sheehy MRJ, Wickins JF (1994) Lipofuscin age pigment in the brain of the European lobster Homarus gammarus (L.). Microsc Anal 40:23-25

Sheehy MRJ, Greenwood JG, Fielder DR (1994) More accurate chronological age determination of crustaceans from field situations using the physiological age marker, lipofuscin. Mar Biol 121:237-245

Sheehy MRJ, Cameron E, Marsden G, McGrath J (1995) Age structure of female giant tiger prawns Penaeus monodon as indicated by neuronal lipofuscin concentration. Mar Ecol Prog Ser 117:59-63

Sheehy MRJ, Shelton PMJ, Wickins JF, Belchier M, Gaten E (1996) Ageing the European lobster Homarus gammarus by the lipofuscin in its eyestalk ganglia. Mar Ecol Prog Ser 143:99-111

Sheehy MRJ, Caputi N, Chubb C, Belchier M (1998) Use of lipofuscin for resolving cohorts of western rock lobster (Panulirus cygnus). Can J Fish Aquat Sci 55:925-936

Sohal RS (ed) (1981) Age pigments. Elsevier, Amsterdam 
Teigmark G (1983) Populations of the deep-sea shrimp (Pandalus borealis Krøyer) in the Barents Sea. Fiskeridir Skr Ser Havunders 17:377-430

Wenner EL (1979) Distribution and reproduction of nematocarcinid shrimp (Decapoda: Caridea) from the northwestern North Atlantic. Bull Mar Sci 29:380-393

Weslawski JM (1987) Distribution of Decapoda (Crustacea) in south Spitsbergen coastal waters with remarks on their ecology and breeding biology. Pol Polar Res 8:121-134
Wienberg R (1981) On the food and feeding habits of Pandalus borealis Krøyer. Arch Fischereiwiss 31:123-137

Zs-Nagy I (ed) (1988) Lipofuscin 1987: state of the art. Proceedings of an International Symposium held in Debrecen, Hungary, 26-30 August 